\title{
Holiday Rentals: The New Gentrification Battlefront
}

\author{
by Agustín Cócola Gant \\ University of Lisbon
}

Sociological Research Online, 21 (3), 10
<http://www.socresonline.org.uk/21/3/10.html>
DOI: $10.5153 /$ sro.4071

Received: 21 Mar 2016 | Accepted: 12 Aug 2016 | Published: 31 Aug 2016

\begin{abstract}
In this paper, I explore the impacts of holiday rentals in the historic centre of Barcelona. The intention is to contribute towards a conceptualisation of this unexplored phenomenon with the aim of better understanding why it represents the new gentrification battlefront in several tourist destinations. I suggest that the rhetoric of the sharing economy conceals the fact that holiday rentals are actually a new business opportunity for investors, tourist companies and individual landlords and, for this reason, long-term residents represent a barrier to capital accumulation. I show that there is an increasing conversion of housing into accommodation for visitors and that such conversion involves different forms of displacement. Importantly, when residents move out, the only buyers tend to be tourist investors. In such a context, I suggest that the growth of vacation flats produces conditions that solely enable the reproduction of further accommodation for visitors, rather than for long-term residential use. I call this process 'collective displacement', that is to say, a substitution of residential life by tourism. Ultimately, throughout this paper I suggest the importance of undertaking critical research relevant to those experiencing urban inequalities. Documenting and producing data about the way in which displacement takes place can be a crucial political tool for those who are fighting for staying put.
\end{abstract}

Keywords: Tourism, Gentrification, Displacement, Holiday Rentals, Airbnb, Barcelona

1.1 The phenomenon of holiday rentals is becoming a central gentrification battlefront in several cities in both the North and the South. A look at the internet shows how residents and activists in different places are expressing concerns about the impacts that vacation flats have in their neighbourhoods, especially after the spread of portals such as Airbnb. Research about the impacts of vacation rentals and how they are contested, however, remains in its infancy. Some authors reveal that behind the rhetoric of the sharing economy there is simply another opportunity for capital accumulation (Arias-Sans \& Quaglieri-Domínguez 2016). The suppliers, far from being single families that occasionally rent the homes in which they live, tend to be the same investors and landlords that were fuelling previous rounds of gentrification. Other authors note that short-term rentals are a central element in the context of growing protests and campaigns that point to tourism as a factor in urban inequality (Colomb and Novy 2016; Füller and Michel 2014; Peters 2016; Opillard 2016). Despite these initial steps, there are no empirical studies that assess the way in which holiday rentals transform communities and, consequently, reveal why they are being resisted and by whom.

By gentrification, I refer to a process of capital investment in the built environment that caters to the demands of affluent users and, along the way, displaces the indigenous population (Lees et al. 2016). I show that the growth of vacation rentals fuels housing rehabilitation and that this increasing conversion of housing into accommodation for visitors entails different forms of displacement. The phenomenon, then, needs to be regarded as an example of tourism gentrification. Also, the conversion of housing into accommodation for visitors is a consequence of the liberalisation of the housing market and the change from housing as shelter towards housing as an investment vehicle (Bone 2014; Cole et al. 2016). To understand why vacation rentals represent the new gentrification battlefront, I focus on the impacts of the process. I explore how displacement takes place and who is affected by it. It is worth noting that although in classical gentrification the middle-classes displace low income 
residents (Butler 2002), in this case both middle and working class residents are being displaced by the pressure of tourist investors. Indeed, the process has an impact on both tenants and owners, which contradicts the liberal rhetoric of home ownership as a protection against displacement. In the next section, I describe the forms of displacement noted by gentrification research. In the following sections I present my methodology and my empirical findings. Finally, I discuss my results and I relate them with the literature on displacement.

\section{Forms of displacement}

2.1 I draw on the conceptualisation of residential displacement advanced by Marcuse (1985) and other authors (Newman and Wyly 2006;DeVerteuil 2011; Slater 2009; Davidson and Lees 2010). The most visible form of displacement is usually 'direct displacement', which refers to an involuntary out-migration from a place. While direct displacement is the most visible form of displacement, Marcuse (1985) also noted that an important but hidden impact of gentrification is 'exclusionary displacement': the difficulties in finding affordable accommodation in gentrifying areas. Marcuse added a final category -'displacement pressure'- which refers to changes at the neighbourhood scale such as loss of social networks, stores or public facilities that are central to everyday life. Marcuse stated that as the area becomes 'less and less livable, then the pressure of displacement already is severe. Its actuality is only a matter of time' (1985: 207). As Davidson and Lees (2010) suggest, displacement means a lot more than simply the moment of eviction. The pressure of displacement has long-term implications that makes it progressively difficult for low-income residents to remain over time.

\section{Methodology and case study}

3.1 This paper is the result of a mixed method research approach that took place in Barcelona between February and October 2015. The case study was the so-called Gòtic neighbourhood in Barcelona's historic centre (Cócola Gant 2014a; 2014b). The area is a middle class neighbourhood that had been experiencing a process of classical gentrification since the early 1990s. A survey of 220 households was conducted with the aim of gathering data about housing conditions and to estimate the supply of holiday rentals. For this purpose, other secondary sources were also used, in particular Airbnb and Inside Airbnb. However, the research emphasised the qualitative approach as the main goal of the project was to give voice to long-term residents in order to examine how the growth of holiday apartments affects them on a daily basis. In this regard, 42 in-depth interviews were conducted as well as participant observation. Community contestation against vacation rentals is a visible practice in Barcelona's city centre (Figure 1). However, I was more concerned with the hidden impacts that holiday apartments have on the everyday lives of residents. I did not ask residents about how they organise their political actions against the growth of tourist accommodation, but instead I asked why such a growth is seen by many as the main cause of tension in the neighbourhood. Importantly, 40 out of the 42 interviewees stated that holiday rentals displace residents. They talked about expulsions, harassment, rent increase, affordability problems, the pressure of tourist investors, daily disruptions and so on. In other words, they reflected different forms of displacement.

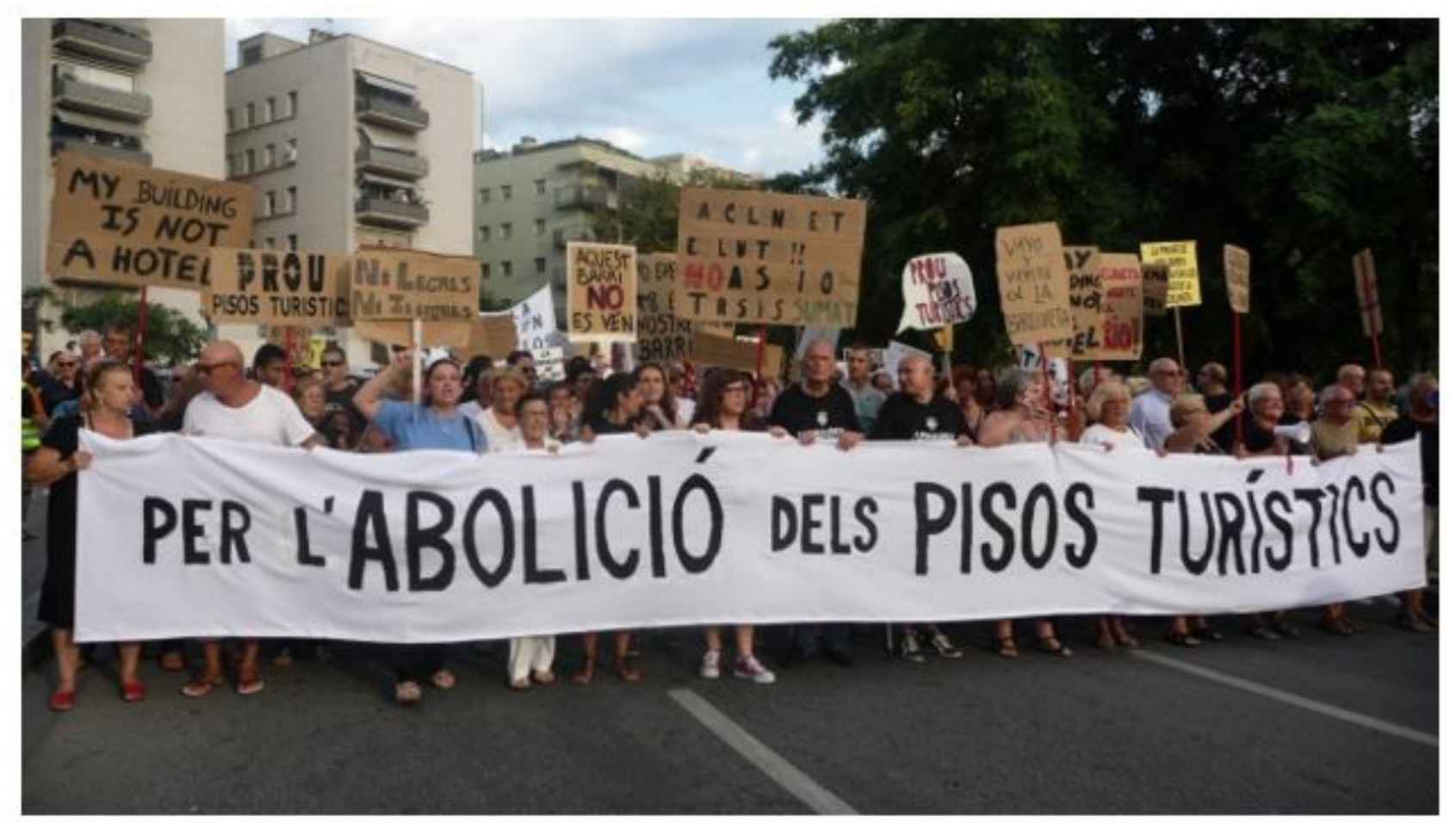


Figure 1. Protests against holiday rentals. Barcelona, August 2014. Photograph by Ernest Cañada.

The question of positionality and how academics get involved in gentrification issues was present in all phases of the research. I believe that gentrification research is a political activity and, consequently, we should make our work more relevant to those people who are at risk of displacement. However, rather than emphasising the spectacular or resistance practices (DeVerteuil 2015), I argue that revealing how displacement takes place is a necessary political tool in confronting the rhetoric of success and growth and in showing the actual conditions in which people experience urban inequalities. In his research in Brooklyn, Slater (2006: 748) depicts how he was told by a community organiser that the best way he could help with local efforts in resisting gentrification was to 'come up with some numbers to show us how many people have been and are being displaced'. As social injustices are visible if only the facts are placed in evidence, making efforts to show how inequalities take place is a central tool for political action, especially to confront the hegemony of city leaders who believe that tourism growth is in the interest of all.

\section{Holiday rentals: supply and impacts}

4.1 In this section, I describe my empirical results, which are organised in three sub-sections. First, I provide a general introduction to holiday rentals in Barcelona. Second, I analyse the supply of holiday rentals, in particular the extent to which housing has been converted into accommodation for visitors. Finally, I analyse my qualitative findings and show the way in which holiday rentals lead to different forms of displacement.

\section{An approximation to holiday rentals in Barcelona}

4.2 The phenomenon of holiday rentals has been documented in Barcelona since the late 1990s. In a period when tourism began to be the main industry in the city, some residents depict how young Americans left flyers in post-boxes with the sentence 'you live in a goldmine'. At this stage it was sporadic, involved middle class guests from North Europe and America and hosts tended to be childless families or young professionals. In the early 2000s, the phenomenon grew. Investors and hotel companies bought entire apartment buildings and transformed them into vacation flats. Some landlords gradually stopped renting to traditional tenants. Lifestyle migrants also bought second homes in Barcelona and rented them to visitors while they are away. Although the number of single families who actually rented the homes in which they lived also grew, in this period holiday rentals became an investment opportunity for many. The important point is that the activity fuelled housing rehabilitation and this involved an increasing conversion of housing into tourist accommodation. It is at this moment when residents experienced community tension and neighbourhood organisations started to complain, a fact that was noted by some scholars (Degen 2004; García \& Claver 2003). It is worth stressing, therefore, that the pressure of vacation flats was already a fact prior to the creation of Airbnb in 2008. What Airbnb has done is to expand the situation that existed before: more business opportunities for investors, tourist companies and landlords, and more visibility for those who rent rooms in their homes.

\section{The supply of holiday rentals}


Nowadays, an exploration of the supply of vacation flats shows the extent to which housing has been converted into accommodation for visitors. Airbnb does not reveal how many apartments they list or how many 'hosts' use the portal. By checking the website, one can only see the number of apartments listed at that moment but it does not show the apartments that have been booked. Therefore, the total number of apartments taken out from the housing stock will always be larger than the apartments listed on Airbnb during any specific day. In any case, data gathered from Airbnb is useful in terms of understanding the phenomenon and in comparing the supply in different areas. The project 'Inside Airbnb' captures such a supply in several cities every few months, including Barcelona. I use the listing captured by Inside Airbnb on 2nd October, 2015, which produces the following distribution:

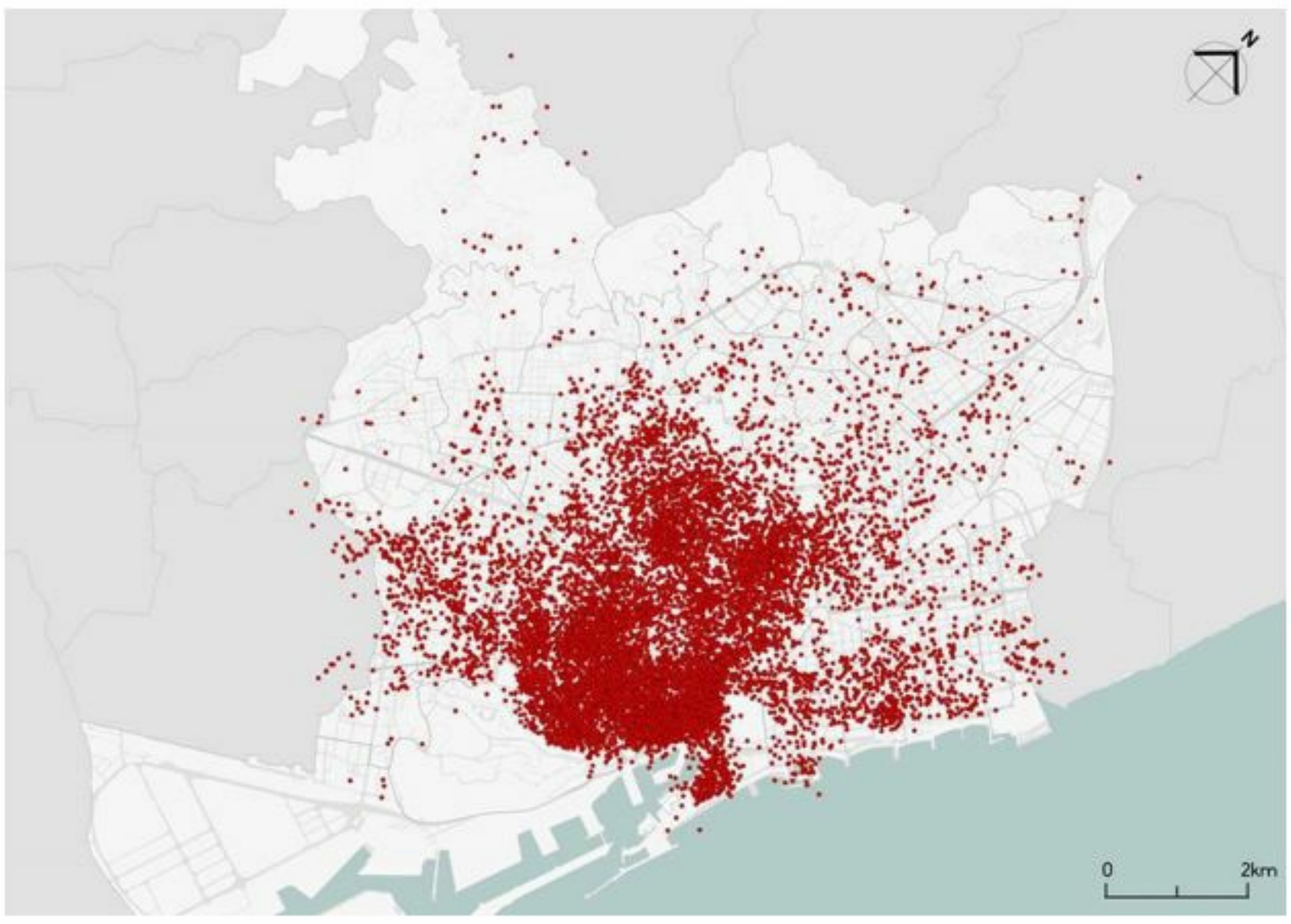

Figure 2. Flats listed in Airbnb Barcelona. 2 October, 2015. Source: compiled from Inside Airbnb. 


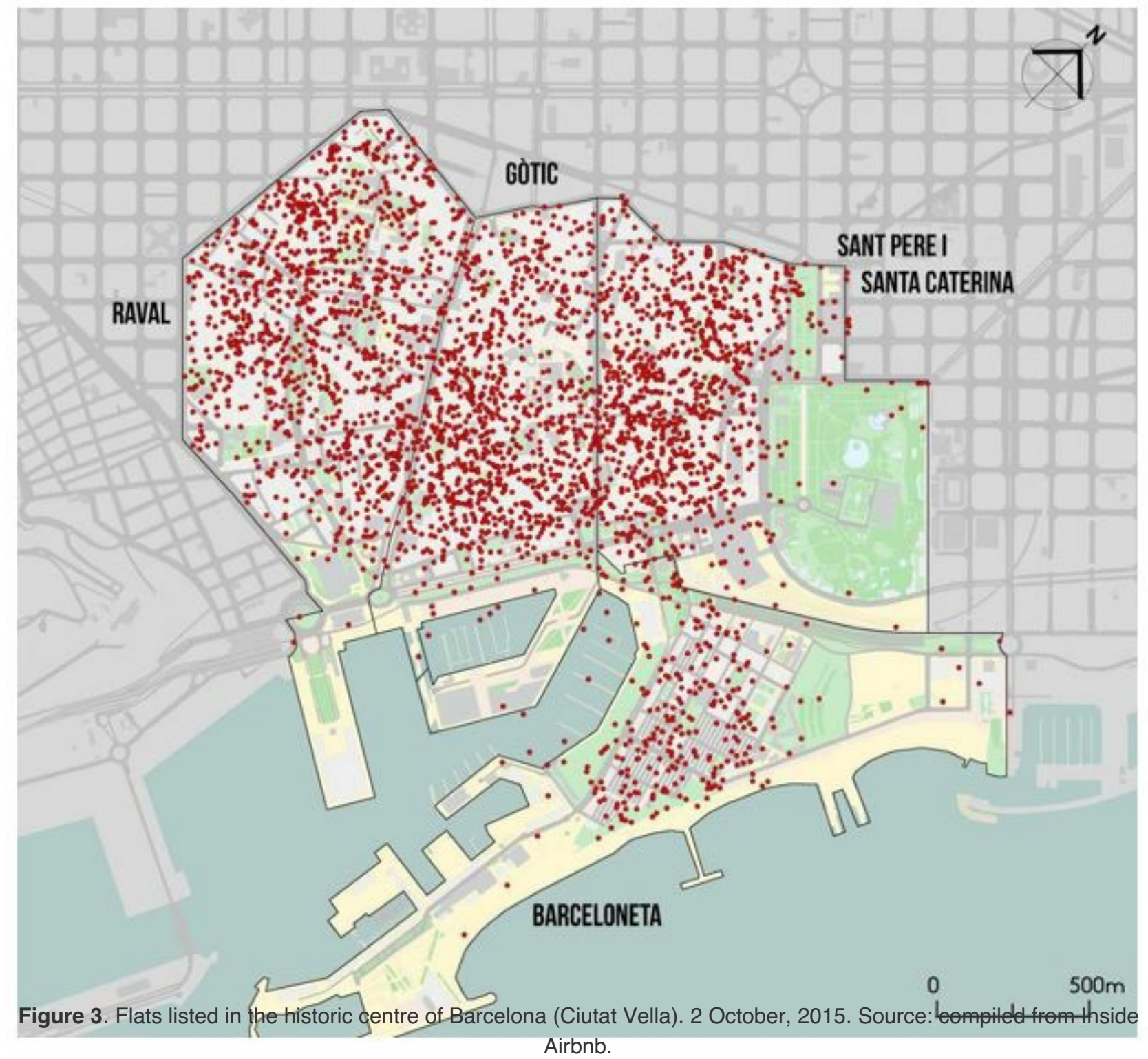

In Barcelona, there were 14,539 flats listed on Airbnb. Interestingly, those flats represent $2.2 \%$ of existing households. However, the phenomenon is uneven and there is a strong concentration in central areas. In the historic centre (the district called Ciutat Vella) the proportion is $9.6 \%$. Ciutat Vella has four neighbourhoods, of which the Gòtic has a proportion of $16.8 \%$. Therefore, in the Gòtic neighbourhood, 1 out of 6 apartments were listed on Airbnb on $2^{\text {nd }}$ October, 2015. These proportions can be seen in the following table:

Table 1. Airbnb listings on 2 October, 2015 and existing households. Source: Inside Airbnb and Barcelona City Council, Statistics. 


\begin{tabular}{cccc}
\hline 2015 & Airbnb listings & Households & $\begin{array}{c}\text { Airbnb / } \\
\text { Households }\end{array}$ \\
\hline Barcelona & 14,539 & 655,175 & 2.2 \\
\hline Ciutat Vella & 3,845 & 39,926 & 9.6 \\
\hline Raval & 1,340 & 16,776 & 7.9 \\
\hline Gòtic & 1,091 & 6,461 & 16.8 \\
\hline S Pere, S Cat., Ribera & 1,111 & 9,869 & 4.4 \\
\hline Barceloneta & 303 & 6,821 & \\
\hline
\end{tabular}

\section{Qualitative results: holiday rentals and displacement}

4.4 This sub-section explores how the conversion of housing into tourist accommodation is experienced by residents. The aim is to better understand the impacts that vacation flats cause on communities and, by so doing, to comprehend why they are being resisted. Put simply, as short-term rentals are an appealing business opportunity, long-term residents represent a barrier to capital accumulation. Notwithstanding, the displacement process is not so straight forward and actually takes several forms. The empirical work confirms the occurrence of the different types of displacement conceptualised by Marcuse (1985): direct displacement, exclusionary displacement and displacement pressures.

4.5 Direct displacement. Processes of direct displacement are a central concern within the community. Ultimately, the 1,191 vacation flats that exist in the Gòtic area once provided accommodation for long-term residents. There are cases in which tenants are economically compensated if they agree to leave prior to the end of the agreement. In other cases, the landlord simply does not renew the contract. Despite the fact that for tenants it is never easy to move out involuntarily, there are several cases in which the eviction process has been more dramatic and violent, especially for lifetime tenants. Harassment and deliberate degradation is being used to force tenants to leave.

4.6 Exclusionary displacement. Although direct displacement is more visible, I argue that exclusionary displacement affects a larger number of residents as they are excluded from the possibility of accessing housing. This exclusion is caused by two interrelated issues. Firstly, the fact that $16.8 \%$ of flats have been taken out of the housing stock means that several landlords and companies do not even consider the idea of renting to residents as they can make higher profits from short-term rentals. Secondly, the latter intensifies the rise in rent prices which in Ciutat Vella is now 9\% higher than the average in Barcelona, despite the fact that in 2007 it was 3\% lower. As a resident states, 'it took me ages simply to find a flat available to long-term residents. But they are so expensive that you cannot afford them on local wages'. The difficulties in finding affordable accommodation accelerates 'classical' gentrification as only middle- and upper-class groups can afford to move to the area. At the same time, exclusionary displacement is at the origin of several strategies implemented by residents who want to remain in the area but for which 'staying put' involves accepting poor living conditions, overcrowding or spending more than $50 \%$ of their income on rent.

4.7 Displacement pressures. On the one hand, the fact that apartment buildings combine residential and tourist uses is the cause of daily cohabitation troubles that have been for many the main reason to move out of the property. There are several types of disruption that affect the private lives of residents. The most frequent is noise and the growing difficulties encountered in resting and sleeping during night time. Several interviewees explained that sometimes visitors do not even know which flat to go and so they try to open residents' doors. These pressures affect all residents and not only tenants. I interviewed a couple who decided to sell their flat and move to a different neighbourhood: 'in the building 14 out of 20 flats were holiday apartments. Some of them were actually youth hostels. And they radically changed our lives (...)'. The coexistence of residential and tourist uses also produces an economic pressure in which residents cannot afford the upkeep of a building increasingly used by visitors. On the other hand, the pressure of tourist investors is on the increase. As a resident explains, 'it is not a coincidence that every week I find in my post-box an offer to buy my flat saying "great opportunity!". The 
thing is that I feel I am trying to resist against something that ultimately says that I am a leftover here. That says: what are you doing here? This place is for tourists'.

\section{Discussion: towards a conceptualisation of collective displacement}

5.1 The description of the way in which holiday rentals are experienced by residents shows that the moment of eviction is not the only form of displacement (Marcuse 1985; Davidson and Lees 2010). Although direct displacement is an important consequence, the process causes indirect impacts that are crucial to understanding community opposition to tourism. From this point of view, understanding displacement pressures involves understanding the lived experiences of residents before direct displacement takes place. But also, I want to stress the importance of exclusionary displacement. The growth of the phenomenon excludes residents from the possibility of accessing housing while also provoking mounting affordability pressures. The current loss of housing stock also means that residents that have suffered direct displacement are unable to find accommodation in the neighbourhood. This point is crucial as it makes it increasingly difficult to reproduce the local community that, instead, is replaced by transient consumers.

I suggest that the growth of tourism and the consequent conversion of housing into accommodation for visitors results in a process of social change that I call 'collective displacement'. Collective displacement needs to be seen as the final consequence of a process in which all forms of displacement come together. First, the growth of tourism causes a progressive out-migration of residents via direct displacement. Second, it is at the origin of housing shortage and price increase, which excludes other residents from the possibility of moving into the area. Third, this exclusion is accelerated by the daily disruptions and economic pressures caused by vacation flats. Finally, such disruptions and the pressure of tourist investors 'force' residents to sell their flats. In such a context, the only buyers tend to be tourist investors, which further intensifies and reproduces the displacement process. In conclusion, the growth of the phenomenon results in a vicious circle that solely enables the reproduction of further accommodation for visitors rather than for long-term residential use. It is a snowball process in which the area loses residents and excludes potential ones from the possibility of moving in. It leads to a form of collective displacement never seen in classical gentrification, that is to say, to a substitution of residential life by tourism.

\section{Final remarks}

6.1 Tourism-driven displacement is central to understanding why vacation flats are resisted. As stressed by Slater (2015), it is important to note that displacement is actively produced and has nothing to do with a supposedly natural functioning of the free market. The process is fuelled by investors, tourist companies and individual landlords for whom the conversion of residential buildings into accommodation for visitors is a new business opportunity. It is also facilitated by the state via the liberalisation of the housing market as it allows such a conversion. By way of contrast, for residents and for those who need a place to live holiday rentals represent the new gentrification battlefront. The phenomenon threatens their right to stay put while making it increasingly difficult for residents to find affordable accommodation. The example of vacation rentals shows the extent to which tourism can be a displacing process and, as such, a process that leads to urban inequalities. This fact opens new questions for gentrification research, but especially for public policy, as it challenges the assumption that the growth of tourism is inherently positive.

6.2 I have suggested that the growth of the phenomenon could lead to a substitution of residential life by tourism. Although further research is needed, this outcome is confirmed by early demographic studies in Barcelona (López-Gay and Cócola Gant 2016) as well as in other tourist destinations (Kesar et al. 2015) that links the growth of vacation rentals to a progressive population decrease. I suggest that this snowball process also needs to be related with changes in the entire character of the place. The mutation of places into spaces of tourism consumption makes everyday life increasingly difficult (Cócola Gant 2015). In this regard, we need empirical studies to explore the extent to which the growth of the tourism industry undermines the use value of neighborhoods as places for social reproduction.

\section{Acknowledgements}

This research is supported by the Portuguese National Funding Agency for Science, Research and Technology (SFRH/BPD/93008/2013) and by the School of Geography and Planning, University of Cardiff. The author is grateful to Geoffrey DeVerteuil and Peter Mackie for their support and supervision and to the anonymous reviewers for their useful comments and suggestions. 


\section{References}

ARIAS-SANS, A \& QUAGLIERI-DOMÍNGUEZ, A (2016) Unravelling Airbnb. Urban perspectives from Barcelona. In Russo, P \& Richards, G (eds.) Reinventing the local in tourism. Travel communities and peerproduced place experiences, London: Channel View.

BONE, J (2014) Neoliberal Nomads: Housing Insecurity and the Revival of Private Renting in the UK, Sociological Research Online Vol. 19, No 4, http://www.socresonline.org.uk/19/4/1.html.

BUTLER, T (2002) Thinking global but acting local: the middle classes in the city,Sociological Research Online Vol. 7, No 3, http://www.socresonline.org.uk/7/3/timbutler.html. [doi:10.5153/sro.740]

CÓCOLA GANT, A (2015) Tourism and commercial gentrification. InThe ideal city. Between myth and reality. RC21 Conference. Urbino: ISA, p. 1-25.

CÓcOLA GANT, A (2014a) El Barrio Gótico de Barcelona. Planificación del pasado e imagen de marca Barcelona: Madroño.

CÓCOLA GANT, A (2014b) The Invention of the Barcelona Gothic Quarter, Journal of Heritage Tourism, Vol. 9, No 1, p.18-34. [doi:10.1080/1743873X.2013.815760]

COLE, I; POWELL, R \& SANDERSON, E (2016) Putting the Squeeze on "Generation Rent": Housing Benefit Claimants in the Private Rented Sector-Transitions, Marginality and Stigmatisation, Sociological Research Online, Vol. 21, No 2, http://www.socresonline.org.uk/21/2/9.html. [doi:10.5153/sro.3909]

COLOMB, C \& NOVY, J (2016) Urban tourism and its discontents: an introduction. In Colomb C \& Novy, J (eds.) Protest and Resistance in the Tourist City. London: Routledge, p.1-30.

DAVIDSON, M \& LEES, L (2010) New-build gentrification: its histories, trajectories, and critical geographies, Population, Space and Place, Vol. 16, No 5, p.395-411.

DEGEN, M (2004) Barcelona's Games: the Olympics, urban design, and global tourism. In Sheller, M \& Urry, J (eds.) Tourism Mobilities: Places to play, places in play London: Routledge, p. 131-142.

DEVERTEUIL, G (2015) Resilience in the Post-Welfare Inner City: Voluntary Sector Geographies in London, Los Angeles and Sydney. Bristol: Policy Press. [doi:10.1332/policypress/9781447316558.001.0001]

DEVERTEUIL, G (2011) Evidence of gentrification-induced displacement among social services in London and Los Angeles, Urban studies Vol. 48, No 8, p.1563-1580. [doi:10.1177/0042098010379277]

FÜLLER, H \& MICHEL, B (2014) 'Stop Being a Tourist! New Dynamics of Urban Tourism in Berlin-Kreuzberg', International Journal of Urban and Regional ResearchVol. 38, No 4, p.1304-1318. [doi:10.1111/14682427.12124]

GARCÍA, M \& CLAVER, N (2003) Barcelona: Governing Coalitions, Visitors and the Changing City Center. In Hoffman, L; Fainstein, S \& Judd, D (eds.) Cities and Visitors: Regulating People, Markets, and City Space, Oxford: Blackwell, p. 113-125. [doi:10.1002/9780470773673.ch6]

KESAR, O, DEZELJIN, R \& BIENENFELD, M (2015) Tourism Gentrification In The City Of Zagreb: Time For A Debate? Interdisciplinary Management Research, Vol. 11, p.657-668.

LEES, L, SHIN, H.B. \& LÓPEZ-MORALES, E (2016)Planetary gentrification. Cambridge: Polity Press.

LÓPEZ-GAY, A \& CÓCOLA GANT, A (2016) Cambios demográficos en entornos urbanos bajo presión turística: el caso del barri Gòtic de Barcelona. In Domínguez-Mújica, J \& Díaz-Hernández R (eds) XV Congreso Nacional de la Población Española. Fuerteventura: Asociación de Geógrafos Españoles, p.399-413.

MARCUSE, P (1985) 'Gentrification, abandonment, and displacement: Connections, causes, and policy responses in New York City', Journal of Urban and Contemporary Law Vol. 28, p.195-240.

NEWMAN, K \& WYLY, E.K (2006) The right to stay put, revisited: gentrification and resistance to displacement in New York City, Urban studies, Vol. 43. No 1, p.23-57. [doi:10.1080/00420980500388710] 
OPILLARD, F (2016) From San Francisco's "Tech Boom 2.0" to Valparaíso's UNESCO World Heritage Site: resistance to tourism gentrification in a comparative political perspective. In Colomb C \& Novy, J (eds.) Protest and Resistance in the Tourist City. London: Routledge, p.129-151.

PETERS, D (2016) Density wars in Silicon Beach: the struggle to mix new spaces for toil, stay and play in Santa Monica, California. In Colomb C \& Novy, J (eds.) Protest and Resistance in the Tourist City. London: Routledge, p.90-108.

SLATER, T (2015) Planetary rent gaps, Antipode, online.

SLATER, T (2009) 'Missing Marcuse: on gentrification and displacement',City Vol. 13 No 2-3, p.292-311. [doi:10.1080/13604810902982250]

SLATER, T (2006) 'The eviction of critical perspectives from gentrification research', International Journal of Urban and Regional Research Vol. 30 No. 4, p.737-757. [doi:10.1111/j.1468-2427.2006.00689.x] 